\title{
SYSTEMIC POLICY AS CRIMINAL POLITICS IN ERADICATING CORRUPTION IN INDONESIA
}

\author{
By \\ WP. Djatmiko* \\ email: djatmiko.ldwd@gmail.com
}

\author{
ARTICLE INFORMATION \\ Article history: \\ Received June 13, 2015 \\ Revised October 25, 2015 \\ Accepted April 23, 2016

\section{JEL Classifications} \\ $\mathrm{H} 59$

\section{Key Words:} \\ Non-penal policy, \\ Corruption, \\ Systemic policy \\ DOI: \\ 10.21532/apfj.001.16.01.02.17
}

\begin{abstract}
Criminal Policy is a rational organization of the control of crime by society, which can be carried out operationally through a penal or non-penal policy. Reality shows that there is a flaw in penal policy in preventing crime act of corruption in Indonesia. Various efforts have been done to eradicate corruption, starting from law enforcement, political will, legislative policy, establishment of special institutions/commissions, improvement and reformation on bureaucracy, law socialization in various circles, and establishment of international cooperation. Yet, all of those efforts have not yielded maximum results. In Indonesia, corruption is still raging. Therefore, the corruption prevention policy should rely on not only penal policy, but also non-penal policy (systemic policy). The corruption prevention policy using systemic approach is a strategic policy as it is more preventive in dealing with corruption. The main goal of systemic policy is to handle and reduce the causative factors of criminal act of corruption.
\end{abstract}

\section{A. INTRODUCTION}

Corruption can be regarded as an old social problem, which may be as old as human civilization itself. Besides, corruption is a universal phenomenon. ${ }^{l}$ Corruption can be interpreted as a form of: rottenness, badness, depravity, dishonest behavior, corruptible tendency, or immoral behavior. $^{2}$ In general, corruption is known as unfair

* PhD Candidate in Criminal Law Science, Diponegoro University, Semarang. Executive Director of the Institute for Law and Labor.

1 In the preamble of UNCAC in 2003, corruption is referred as a transnational phenomenon.

2 Andi Hamzah, Pemberantasan Korupsi Melalui Hukum Pidana Nasional dan Internasional (Edisi Revisi 2007), Jakarta, PT. Raja Grafindo Persada, 2007, p. 6-7. 
practices that are detrimental to the state finances, misappropriation or embezzlement of state funds for personal benefit, or others. ${ }^{3}$

Corruption always exists in people's lives either in the developed countries, in the newly industrialized countries (NIC), or in the developing countries. The levels of corruption in a country are largely determined by the multi-facet and interrelated factors. A general assumption states that the increasingly closer to developing country, the higher level of corruption in the country. But strangely, it does not reflect the condition in Indonesia.

Although Indonesia has belonged to NIC category, the level of corruption is still very high. The Corruption Perception Index (CPI) released by Transparency International Indonesia (TII) in 2013 shows that Indonesia is ranked 118 out of 177 countries surveyed. The ranking of Indonesia is under the ASEAN countries such as Singapore, Malaysia, the Philippines, Thailand, and even Timor Leste. ${ }^{4}$ As for the group of investors, especially from Asia, corruption in the courts (Indonesia) in the last decade obtained a score of 9.92 on a scale of 1 to 10 with a note that score 1 is for the best. ${ }^{5}$ Hopefully, this condition could be better in the next period.

Corruption has become one of the major and serious problems being faced by Indonesian

3 Aziz Syamsuddin, Tindak Pidana Khusus, Jakarta, Sinar Grafika, fourth printing, 2014, p. 15.

4 See,http://www.antikorupsi.org/id/content/ indonesia-terkorup-No.-36-survei-transparencyinternational, accessed on June 9, 2015.

5 Arya Maheka, Mengenali dan Memberantas Korupsi, Jakarta, KPK, 2006, p.2. people. Recent phenomenon occurring in Indonesia indicates that corruption is committed not only individually but also in groups, in a single unit of work. ${ }^{6}$ Various attempts have been made to eradicate corruption, starting from political will, legislative policy, establishment of bodies / special commissions, law enforcement, improvement and reform of the bureaucracy, socialization of law in some quarters, to the establishment of international cooperation. However, all these attempts have not yielded maximum results.

The high level of corruption in Indonesia indicates that corruption in Indonesia has expanded in various fields of people's lives and has taken place in a relatively long period of time, resulting in the accumulation of state financial losses and the loss of the country's economy. In addition, corruption also affects the level of people's welfare.

As campaigned globally, corruption can ruin the effectiveness of all kinds of potential government programs. Corruption may also interfere / impede development, causing the victims of individual and community groups. ${ }^{7}$ Besides, corruption may endanger the stability and social security, ruin the values of democracy and morality aspect, and endanger the national economy. ${ }^{8}$ Furthermore, corruption

6 Surachim and Suhandi Cahaya, Strategi dan Teknik Korupsi: Mengetahui Untuk Mencegah, Jakarta, Sinar Grafika, 2011, p. 31.

7 Contained in resolution "Corruption in government" $8^{\text {th }}$ UN Congress of 1990 on "The Prevention of Crime and the Treatment of Offenders" in Havana (Cuba).

8 Expressed in the $9^{\text {th }}$ UN Congress of 1995 in Cairo, Egypt. 
is also endangers security and stability of social institutions, devastates democratic system, and threatens political stability. ${ }^{9}$

Corruption, therefore, must be eradicated thoroughly in a comprehensive manner. The eradication of corruption should be done using systemic approach, an approach occurring out of judicial system. This approach prioritizes preventive aspect with the aim to be able to reduce or eliminate corruption. So, this approach is always oriented on the efforts to take precautions in order to avoid from corruption.

Systematic corruption eradication needs to be implemented immediately. Repressive corruption eradication (penal) seems not to produce maximum results. Criminal law frequently faces many constraints in tackling massive corruption such as in Indonesia. The constraints include: (1) the effectiveness depends on the capability of supporting infrastructure; (2) the corruption is caused by very complex causes; (3) the criminal law is actually only a small part of the means of social control; (4) the role of criminal law is just as kurieren am symptom, not causative; (5) the criminal sanction is just remedium that contains negative elements and side effects; (6) the system of punishment in Indonesia is just fragmentair. Therefore, systemic policies that embody preventive actions should be immediately maximized to minimize potential losses to the state finances and the loss of the country's economy in larger quantities.

\footnotetext{
9 In the UN Convention Against Corruption accepted by UN General Assembly on October 31, 2003.
}

In general, corruption in Indonesia is caused by some factors, such as ${ }^{10}$ : (1) lack of salary or income for state employees; (2) cultural background of Indonesia; (3) unfavorable management; (4) modernization which feeds corruption.

Indonesian people are dreaming of the state officials who are clean and free of corruption, the community with anti-corruption culture, and the government system with all subsystems that do not allow any corruption. Bureaucracy should be clean and not corrupt so that the community will also be clean, because corruption in bureaucracy may reflect the condition of society as a whole. ${ }^{11}$ This is obviously easy to say but very hard to achieve. Only with the growth of the will and the collective consciousness of every member of this great nation can the dream be realized. In other words, the main factor is on the human as an actor in the system of the country. Thus, it is not only the system of legislation that must be perfect and adequate, but also the human as the main actor who must have personality and good behavior. He should have adequate ability and integrity as well as high awareness in compliance with applicable regulations, with regard to both law enforcement officials and all members of society.

\section{B. Formulation of the Problem}

Based on the description above, the formulation of the problem in this paper

\footnotetext{
10 Andi Hamzah at al., Kejahatan-Kejahatan Yang Membahayakan Dan Merugikan Negara, Jakarta, Bina Aksara, 1987, p. 392.

11 Evi Hartanti, Tindak Pidana Korupsi, Jakarta, Sinar Grafika, 2005, p. 19.
} 
includes:

1. Why is systemic policy used as criminal politics in eradicating corruption in Indonesia?

2. What manifestation of systemic policy is used in eradicating corruption in Indonesia?

\section{Discussion}

\section{Systemic policy as criminal politics in eradicating corruption in Indonesia.}

Sudarto confirms that a clean government cannot be realized only by legal regulations, even by the enforcement of criminal law with harsh sanctions. The scope of criminal law is very limited. Indirectly, the efforts to eradicate corruption can be done by applying field actions such as in the sectors of politics, economy and so forth. ${ }^{12}$

Meanwhile, Muladi states that the enforcement of criminal law within the framework of the criminal justice system cannot be expected as the only means of effective crime eradication, given that there might still be the perpetrators of criminal acts outside the framework of the criminal justice process. ${ }^{13}$

On the other hand, Donald R. Taft at.al, as cited by Barda Nawawi Arief, assert that the effectiveness of the criminal law cannot be measured accurately. Law is actually just one of the instruments of social control. Habits, religious beliefs, support, defamation from pressure group and the influence of the public

12 Sudarto, Hukum dan Hukum Pidana, Bandung, Alumni, 2007, p. 124.

13 Muladi, Kapita Selekta Sistem Peradilan Pidana, Semarang, Badan Penerbit Universitas Diponegoro, 1995, p. vii. opinion are more efficient instruments to regulate human behavior than law sanction. ${ }^{14}$

Referring to the reasoning in the $\mathrm{UN}$ Congress, the fundamental strategy in preventing crimes (including the criminal act of corruption) includes two main things:

1. Causative prevention, which means to eliminate the causes and conditions giving rise to crime. ${ }^{15}$

2. Systemic approach, which means to take crime prevention efforts that are not simplistic and fragmented, but departing from various approaches or other social policies that include social, cultural, economic, political, educational, and religious aspects. ${ }^{16}$

By comparing between penal approach and systemic approach in eradicating corruption, it can be seen that systemic approach has more advantages than the penal approach.

This is in line with the United Nations Convention Against Corruption (UNCAC), which states that systemic approach has

14 Donald R. Taft and Ralph W. England in Barda Nawawi Arief, Beberapa Aspek Kebijakan Penegakan dan Pengembangan Hukum Pidana, Bandung, PT. Citra Aditya Bakti, 1998, p. 42.

15 In the $6^{\text {th }}$ UN Congress, in 1980 in Caracas, Columbia, it is stated "Crime prevention strategies should be based on the elimination of causes and conditions giving rise to crime". See, the $7^{\text {th }}$ UN Congress of 1985 in Milan, Italy that "The basic crime prevention strategy must consist in eliminating the causes and conditions that breed crime" and "The basic crime prevention must seek to eliminate the causes and conditions that favor crime"

16 In the $10^{\text {th }}$ UN Congress of 2000, in Wina, Austria, that "Comprehensive crime prevention strategies at the international, national, regional and local levels must address the root causes and risk factors related to crime and victimization through social, economic, health, educational and justice policies". 
advantages as follows: (a) penal policy requires a very high cost; (b) the fund corrupted is often difficult to return to the state; (c) the rampant corruption indicates that the purpose of punishment is not achieved to the fullest; (d) the very broad impact of corruption cannot be addressed by penal approach only; (e) the justice system is still vulnerable to the acts of collusion, corruption and nepotism; (f) the formulation of criminal offense has limitations compared with the development of the mode of crime; $(\mathrm{g})$ the law enforcement is often in conflict with the principle of legality; (h) the possibility of the complexity of evidence on the formulation of the offense in a relatively new mode of crime is unavoidable; (i) the effective prevention can minimize and control the factors of crime. ${ }^{17}$

\section{The manifestation of systemic policy in eradicating corruption in Indonesia.}

Understanding the phenomenon of corruption in Indonesia more comprehensively will facilitate the way to overcome it. It is necessary to improve and perfect the strategies that have been implemented. The experience shows that the establishment of Anti-Corruption Agency (KPK), as part of anti-corruption programs, seems not to be optimal to tackle the widespread corruption, in addition to the presence of constraints of legal substance, legal

17 The existence of non-penal policy as the most strategic policy in criminal politics has ever been asserted in several UN congresses on the Prevention of Crime and the Treatment of Offenders, such as in the $6^{\text {th }} \mathrm{UN}$ congress Caracas, Venezuela in 1980, in the $7^{\text {th }}$ UN Congress in Milan, Italy in 1985, in $8^{\text {th }}$ Congress in Havana, Cuba, in 1990 , and in the $10^{\text {th }}$ UN Congress in Wina, Austria in 2000. culture and legal structure.

Therefore, the public movement campaigns that actively serve as co-government (government partners in supervision) will give a greater opportunity to narrow the chance of corruption and at the same time contribute to fight against corruption. ${ }^{18}$

Ideally, a good anti-corruption strategy is a strategy that has considered all the factors that influence the emergence of the possibility of corruption. Thus the strategy to combat corruption must start from the idea to seek the cause of corruption and then eliminate it. ${ }^{19}$ But, finding the right therapy requires correct diagnosis $^{20}$ and it is not an easy task, because corruption has been multi-facet and rooted in the culture.

Anti-corruption strategy must also be aimed at strengthening the participation of the wider community, including Non Governmental Organizations (NGOs) and the media to monitor the government performance. Thus, public accountability and community participation are important instruments in tackling corruption in Indonesia ${ }^{21}$.

18 Iwan Gardono Sujatmiko, Hypercorruption dan Strategi Pemberantasan Korupsi", Jurnal Krinimologi Indonesia, Vol. 2, No. 1, Januari 2002, Jakarta, Universitas Indonesia, p. 25.

19 Andi Hamzah, Korupsi di Indonesia, Masalah dan Pemecahannya, Jakarta, PT Gramedia, 1991, p.15.

20 Adnan Buyung Nasution dkk., Korupsi, Kolusi dan Nepotisme di Indonesia, Jogyakarta, Aditya Media, 1999, p.iii. Bandingkan dengan pendapat Leden Marpaun. Lihat, Leden Marpaung, Tindak Pidana Korupsi : Pemberantasan dan Pencegahan, Jakarta, Djambatan, 2004, p. 82.

21 Teguh Kurniawan, Peran Akuntabilitas Publik dan Partisipasi Masyarakat dalam Pemberantasan 
The manifestation of non-penal efforts (systemic) to prevent corruption includes:

a. Rethinking, reshaping and redesigning models of public services, especially in all matters relating directly to the activities of the public service. Priority is aimed at: (a) the improvement of public service system; (b) the improvement of the performance of public service officers; (c) the improvement of the performance of public service institutions; and (d) the improvement of the control of public services.

b. Strengthening supervision and sanctions on government activities relating to economic and human resources. Priority is aimed at: (a) the improvement of the financial management system of the State; (b) the improvement of procurement system (procurement of the government goods and services; and (c) the improvement of human resource management system of the state administration.

c. Increasing the empowerment of supporting devices in the prevention of corruption ${ }^{22}$ by involving NGOs and religious leaders as well as community leaders.

d. The disclosing information by the government, which means that the entire government systems related to the implementation of government programs involving sub-system input, sub-systems process and sub-systems output should

Korupsi Pemerintahan, Jurnal Ilmu Administrasi dan Organisasi, vol. 16, no. 2, 2009, Jakarta, FISIP UI, p. 120.

22 See, http://www.bappenas.go.id, accessed on June 10,2015 be made as transparent as possible and accessible.

e. The willingness and the obligation to report wealth for all state employees, especially the officials, honestly and periodically. This report will later be used as one of the instruments for the purpose of promotion and career development of the employees. This is very important to do as a filtering effort to avoid the passing of corrupt officials to the positions of high authority.

f. Improving the function and the role of mass media (electronic and non-electronic) responsibly as a means of supervision on criminal justice system (SPP) and government policies in general. The mass media is also beneficial to carry out the functions of social control. It is very important to prevent the abuse of power, corruption, collusion, nepotism, fraud and other irregularities.

g. Utilizing information technology (IT) and communication to help prevent corruption. Through the application of integrated electronic government (e-government) at the level of central, provincial, and local government will be able to minimize administrative errors and delays in the public service. Besides, the serious application (not just lip service) of electronic procurement (e-procurement) for the procurement of goods and services within government agencies will be able to narrow the opportunities for corruption.

h. The corruption prevention efforts must also be pursued with moral reform. ${ }^{23}$ Moral

23 Ibrahim Shihata, Corruption: The Enemy Within, 
reform is a cultural strategy that is addressed not only to the state employees but also to the community. One of prominent moral reforms to gain the attention is "honesty". The increasing number of corruption is an indicator of the absence of honesty.

i. The value of honesty is very close to the value of truth and justice which is a basic value of life. In the teachings of Islam, for example, honesty is an ideal facet of behavior. ${ }^{24}$ Honest attitude in upholding justice is a fundamental moral value voiced by Islam and other religions. Building religious life and doing goodness are among other things that can be seen in Resolution 3 of the $6^{\text {th }}$ United Nations Congress of $1980 . .^{25}$ Thus, the prevention of corruption should also be achieved through religious approach. The role of religious leaders, religious preachers and religious teachers is needed for the campaign of "honesty" movement.

\section{Conclusion}

Eradication of corruption in Indonesia is done through penal policy and emphasizes comprehensively and earnestly through a systemic approach. Repressive efforts remain to be done in order to give a deterrent effect. But the systemic approach (preventive measure) is very urgent to be done and optimized.

The means to eradicate corruption in

The Hague, Kluwer Law International, 1997, p. 264-269.

24 Al-Qur'an, Surah At-Taubah verse 119: "O those who believe, fear Allah and be with those who are true/honest."

25 The statement is: "Crime prevention strategies should be based on exalting the spirit of man and reinforcing his faith in his ability to do good". systemic ways can be done by improving the government system and its sub-system component primarily related to public services, improving the management system of government human resources, affecting people's views about the need for honesty, the risk of corruption crimes and efforts of 'trial by the press' for the corruptors, religious campaigns, as well as the use of IT in supporting the relation between the public and the government / state and vice versa.

\section{Suggestion}

Based on the conclusion above, some important things that can be suggested are: (1) the eradication of corruption using a systemic approach (out of criminal law) must be carried out seriously and continuously; (2) the involvement of religious leaders, community leaders, NGOs and government is greatly needed; (3) this systemic approach should be aimed primarily at influencing people's views on education facilities and public awareness of the law, encouraging a culture of shame to commit corruption, and fostering a culture of honesty; (4) trial by the press should be encouraged to reinforce a culture of shame and used as a deterrent factor so that anyone should behave honestly, feel embarrassed when committing corruption.

\section{References}

\section{A. Books}

Arief, Barda Nawawi, 1998, Beberapa Aspek Kebijakan PenegakandanPengembangan Hukum Pidana, Bandung: PT. Citra Aditya Bakti. 
Hamzah, Andi, 2007, Pemberantasan Korupsi Melalui Hukum Pidana Nasional dan Internasional (Edisi Revisi 2007), Jakarta: PT. Raja Grafindo Persada. . 1991, Korupsi di Indonesia, Masalah dan Pemecahannya, Jakarta: PT Gramedia. Dkk, 1987, Kejahatan-Kejahatan Yang Membahayakan Dan Merugikan Negara, Jakarta: Bina Aksara.

Hartanti, Evi, 2005, Tindak Pidana Korupsi, Jakarta: Sinar Grafika.

Maheka, Arya, 2006, Mengenali dan Memberantas Korupsi, Jakarta, KPK.

Marpaung,Leden, 2004, Tindak Pidana Korupsi : Pemberantasan dan Pencegahan, Jakarta: Djambatan.

Muladi, 1995, Kapita Selekta Sistem Peradilan Pidana, Semarang: Badan Penerbit Universitas Diponegoro.

Nasution, Adnan Buyung, dkk., 1999,Korupsi, Kolusi dan Nepotisme di Indonesia, Jogyakarta: Aditya Media.

Shihata, Ibrahim, 1997, Corruption: The Enemy Within, The Hague, Kluwer Law International.

Steinberg, Sheldon S. dan David T. Austern, 1999, Government, Ethics, and Managers, Penyelewengan Aparatur Pemerintahan, Bandung: Remaja Rosalakarya.

Sudarto, 2007, Hukum dan Hukum Pidana, Bandung: Alumni.
Surachim dan Suhandi Cahaya, 2011, Strategi dan Teknik Korupsi: Mengetahui Untuk Mencegah, Jakarta: Sinar Grafika.

Syamsuddin, Aziz, 2014, Tindak Pidana Khusus (Cetakan keempat), Jakarta: Sinar Grafika.

\section{B. Journals / Papers / Seminar Materials}

Arief, Barda Nawawi, Beberapa Masalah Penegakan Hukum Pidana dalam Pemberantasan Korupsi, disampaikan dalam Seminar CLC, pada 30 Juli 2005.

Kurniawan, Teguh, Peran Akuntabilitas Publik dan Partisipasi Masyarakat dalam Pemberantasan Korupsi Pemerintahan, Jurnal Ilmu Administrasi dan Organisasi, vol. 16, no. 2, 2009, Jakarta: FISIP UI.

Sujatmiko, Iwan Gardono, Hypercorruption dan Strategi Pemberantasan Korupsi", Jurnal Krinimologi Indonesia, Vol. 2, No. 1, Januari 2002, Jakarta: Universitas Indonesia.

\section{Legislations and Other Sources}

Al-Qur'an, (Surah An-Nisa, verse 135 and Surah At-Taubah, verse 119)

KUHP (Pasal 423 dan 425)

The $10^{\text {th }}$ UN Congress Resolution, in 2000 in Wina, Austria

The $9^{\text {th }}$ UN Congress Resolution, in 1995 in Cairo, Egypt.

The $8^{\text {th }}$ UN Congress Resolution, in 1990 in Havana, Cuba.

The $7^{\mathrm{h}}$ UN Congress Resolution, in 1985 in Milan, Italy 
The $10^{\text {th }}$ UN Congress Resolution, in 1980 in

Caracas, Venezuela

UN Convention Againts Corruption accepted by UN General Assembly on October 31, 2003.

UU No. 40 Tahun 1999 Tentang Pers (Pasal 3 Ayat 1 dan 2)

\section{Internet}

http://www.antikorupsi.org/id/content/ indonesia-terkorup-no.-36-surveitransparency-international, diakses pada tanggal 9 Juni 2015.

http://www.bappenas.go.id, diakses pada tanggal 10 Juni 2015. 
Junaidi : Analysis of The Role of BPK in Preventing.....

Page 205-213 